Background: Chronic airway diseases are often associated with marked mucus production, however, little is know about the regulation of secretory activity by locally released endogenous mediators.

Aim: This investigation was performed to determine the release of MUC5AC mucin from human bronchial preparations using the purinergic agonists adenosine 5'-triphosphate (ATP) and uridine 5'-triphosphate (UTP).

Methods: Immunohistochemical and immunoradiometric assays (IRMA) were used to de tect the MUC5AC mucin. Immunohis tochemical analysis were performed using individual 1-13 M1 and 21 M1 MAbs recognizing a recombinant M1 mucin partially encoded by the MUC5AC gene. IRMA measurments were performed using a mixture of eight anti-M1 mucin MAbs (PM8), which included both 1-13 M1 and 21 M1 MAbs. Lysozyme and protein were also measured in the biological fluids derived from human bronchial preparations obtained from patients who had undergone surgery for lung carcinoma.

Results: The anti-M1 monoclonal antibodies labelled epithelial goblet cells. After challenge of human bronchial preparations with ATP, the goblet cells exhibited less staining. In contrast, UTP did not alter the im m unolabelling of goblet cells. MUC5AC mucin in the bronchial fluids derived from ATP-challenged preparations was increased while UTP had no effecton release. ATP did not alter either the quantities of lysozyme or protein detected in the biological fluids. Conclusion: These results suggest that ATP may regulate epithelial goblet cell secretion of MUC5AC mucin from human airways in vitro.

Key words: ATP; M1/MUC5AC mucins; Human airways; Goblet cells; Secretion

\section{ATP induced MUC5AC release from human airways in vitro}

\author{
Patricia Roger ${ }^{1}$, Jean-Pierre Gascard ${ }^{1}$, \\ Jacques Bara ${ }^{3}$, Vincent Thomas de Montpreville², \\ Micheal Yeadon ${ }^{4}$ and Charles Brink ${ }^{1, C A}$
}

\begin{abstract}
'Laboratoire de Pharmacologie Pulmonaire CNRS ESA 8078, ${ }^{2}$ Laboratoire d'Anatomo-pathologie, Hôpital Marie Lannelongue, 133 Av de la Résistance, 92350 Le Plessis Robinson, France, ${ }^{3}$ INSERM U 482, Hôpital Saint Antoine, 184 rue du Faubourg Saint Antoine, 75012 Paris, France, ${ }^{4}$ Discovery Biology II, Central Research Division, Pfizer Limited, Sandwich, Kent, CT13 9NJ, UK
\end{abstract}

\footnotetext{
${ }^{\mathrm{CA}}$ Corresponding Author

Tel: (33) 0140942800

Fax: (33) 0146301208

E-mail: charlesbrink@hotmail.com
}

\section{Introduction}

Experimental models have shown that secretory activity in respiratory tissues may be regulated by neutrophil elastase ${ }^{1}$, inflammatory mediators such as tumor necrosis factor- $\alpha^{2}$, platelet-activating factor ${ }^{2,3}$ and purinergic agonists such as ATP and UTP. ${ }^{5-6}$ In these reports the release of mucins from epithelial cells was monitored either by immunoassays with various antibodies ${ }^{2,3,7}$, incorporation of radiolabels such as ${ }^{3} \mathrm{H}$-glucosamine into secretory cells ${ }^{6,8-10}$ or videomicroscopy by measuring the degranulation rate of goblet cells after stimulation with purinergic agonists. ${ }^{4,5}$ Although these studies provided information on the effects of agonists on secretory activity, the specific subclass of mucins released subsequent to cell stimulation has not been clearly established.

Recently, Labat and coworkers ${ }^{11}$ studied the secretion of MUC5AC mucin from human airway tissues and demonstrated that human bronchial ring preparations challenged with a variety of agents failed to release the MUC5AC mucin from epithelial goblet cells. These results suggested that the release of mucins from human goblet cells may be regulated by another mechanism.

Since purinergic agonists have been reported to cause degranulation of goblet cells and induce the release of glycoproteins, the aim of this study was to evaluate the effects of ATP and UTP on the release of MUC5AC mucin from human bronchial preparations using both immunohistochemical and immunoradiometric assays (IRMA). This investigation was performed to examine whether or not specific mucins were liberated when goblet cells of human airways were activated by these agonists.

\section{Materials and methods}

\section{Tissues}

Human lung tissues were obtained from 14 patients who had undergone surgery for lung carcinoma. 
Tissues were obtained from the resected lung at a distance from the tumor area. Subsequently, the bronchi (first to third generation bronchi) were dissected free from the parenchyma tissue and washed with Tyrode's solution, $\mathrm{pH} 7.4$ as previously described by Sossé-Alaoui. ${ }^{12}$ Bronchial tissues were cut as rings of constant length and wet weight (4-7 mm internal diameter and 100-500 $\mathrm{mg}$ wet weight). A total of 26 bronchial preparations were examined.

\section{M1 mucin standard and monoclonal antibodies}

M1 mucins isolated from an ovarian mucinous cyst fluid were used as standard. Eight MAbs raised against epitopes associated with the peptide core of M1 mucins allowed the detection of mucins. ${ }^{13}$ These antiM1 mucin MAbs are $\operatorname{IgG}_{1}$. Immunohistochemical analysis were performed using individual 1-13 M1 and 21 M1 MAbs recognizing a recombinant M1 mucin partially encoded by the MUC5AC gene. ${ }^{14}$ IRMA experiments were performed using a mixture of eight anti-M1 mucin MAbs (PM8), which included both 1-13 M1 and 21 M1 MAbs.

\section{Immunohistochemical analysis}

Control tissues and preparations challenged with extracellular ATP and UTP (0.1 mM; Sigma Chemical Co., St Louis) were fixed in formalin for 12 hours, dehydrated, embedded in paraffin and sections of tissues $(5 \mu \mathrm{m})$ were cut. Tissue sections were deparaffinized with toluene, rehydrated with a gradient of ethanol and rinsed in phosphate buffered saline (PBS) $10 \mathrm{mM}, \mathrm{pH} 7.4$ containing $0.1 \%$ Tween 20. Sections were then treated with $0.025 \%$ pronase $\mathrm{E}$ (Calbiochem, France) in $0.05 \mathrm{M}$ Tris- $\mathrm{HCl}$ buffer, $\mathrm{pH}$ 7.6 for $7 \mathrm{~min}$ at room temperature to unmask the mucin epitopes. ${ }^{15}$ After several washes of sections in PBS-0.1\% Tween 20, endogenous peroxidases were eliminated with $3 \% \mathrm{H}_{2} \mathrm{O}_{2}$ in methanol for $5 \mathrm{~min}$. Tissues sections were then incubated in PBS-0.1\% Tween 20 containing 1\% BSA (Sigma Chemical Co., St Louis) for 5 minutes at room temperature and incubated with the individual 1-13 M1 and $21 \mathrm{M} 1$ MAbs at the final concentration of $10 \mu \mathrm{g} / \mathrm{ml}$ in PBS$1 \%$ bovine serum albumin (BSA) for 1 hour. A negative control was also performed by incubating bronchial rings sections with PBS-1\% BSA for 1 hour. After several washes with PBS-0.1\% Tween 20, tissues sections were incubated with horseradish peroxidase conjugated anti-mouse IgG (Sigma Chemical Co., St Louis) diluted in PBS for 1 hour at room temperature. The peroxidase activity was revealed using the diaminobenzidine $/ \mathrm{H}_{2} \mathrm{O}_{2}$ revelation system as described in the LSAB-2 kit (Dako Laboratories, USA) for 10 minutes in darkness and tissues sections were counter-stained with Harris hematoxylin.

\section{Periodic acid Schiff (PAS) staining}

Tissue sections $(5 \mu \mathrm{m})$ from control tissues and ATPchallenged bronchial preparations were deparaffinized and rehydrated as described above. Sections were then treated with $0.5 \%$ periodic acid for 10 minutes, washed in distilled water and stained with Schiff reagent (Surgipath, UK) for 30 minutes at room temperature. After several washes in distilled water, sections were counter-stained with Harris hematoxylin.

\section{Functional studies}

The human bronchial preparations were placed in separate wells of a 24-well plate (Costar, UK) containing $1 \mathrm{ml}$ of Tyrode's solution and equilibrated for 1 hour at $37^{\circ} \mathrm{C}$ in a humidified incubator $\left(5 \% \mathrm{CO}_{2} /\right.$ air). At the end of this equilibration period, the medium was exchanged and fresh Tyrode's solution previously warmed at $37^{\circ} \mathrm{C}$ was added. After 1 hour the bronchial fluids containing the human secretory mucins (Period I; basal release) were collected. Fresh medium (Tyrode's solution) was added for 30 minutes to the bronchial preparations. After this period of pretreatment, the medium was again removed and bronchial rings were placed in Tyrode's solution containing either ATP $(0.1 \mathrm{mM})$ or UTP $(0.1 \mathrm{mM})$ for 1 hour. In some preparations, a short time-course study was performed by stimulating the bronchial preparations with ATP $(0.1 \mathrm{mM})$ or UTP $(0.1 \mathrm{mM})$ in Tyrode's solution for 10, 20, 30, 40 and 60 seconds. At each time, bronchial fluids were collected and stored. In another series of experiments, the effects of ATP and UTP were examined in preparations stimulated for 5 , 30 and 60 minutes with these agents (Period II; stimulation). The bronchial fluids were collected at each Period and stored at $-20^{\circ} \mathrm{C}$.

\section{Immunoradiometric assay (IRMA)}

A solid-phase double-antibody-sandwich immunoradiometric assay (IRMA) was used as previously described. ${ }^{16}$ Polystyrene stars (Oris Industrie, Saint Quentin en Yvelines, France) were coated with the 1-13 M1 MAb $(10 \mu \mathrm{g} / \mathrm{ml}$ in $0.01 \mathrm{M} \mathrm{PBS}, \mathrm{pH} 7.4)$ by incubating overnight at $37^{\circ} \mathrm{C}$, rinsed three times with PBS-0.1\% Tween 20 and subsequently incubated in PBS-1\% BSA overnight at $37^{\circ} \mathrm{C}$. After several washings, stars were dried at $40^{\circ} \mathrm{C}$ and stored at $4^{\circ} \mathrm{C}$ until used. The M1 mucin standard $(10 \mu \mathrm{g} / \mathrm{ml})$, as well as human bronchial fluids were serially diluted in PBS-0.1\% Tween 20. A volume of $300 \mu$ l of each dilution was added to the 1-13 M1 MAb coated-stars and incubated overnight at $37^{\circ} \mathrm{C}$. Stars were then washed with PBS$0.1 \%$ Tween 20 and incubated with PM8 MAbs previously radiolabelled with ${ }^{125} \mathrm{I}\left(5 \times 10^{5} \mathrm{cpm} / \mathrm{ml}\right)$ overnight at $37^{\circ} \mathrm{C}$. Subsequently, the stars were 
washed and the radioactivity was measured in a scintillation counter (Wizard Model 147 005). The concentration of mucin contained in the human bronchial fluids was estimated from the IRMA standard curve obtained with the M1 mucin standard. Mucin concentrations were determined in bronchial fluids derived from 14 lungs (controls and ATPchallenged bronchial preparations) and 6 lungs (UTPchallenged preparations).

\section{Protein determination}

Determination of total protein was performed systematically on an aliquot $(100 \mu \mathrm{l})$ taken from human bronchial fluids collected from control and stimulated bronchial preparations. Total proteins were measured using the Lowry procedure ${ }^{17}$ with BSA as standard.

\section{Assay of lysozyme}

Lysozyme was assayed by measuring the rate of lysis of a suspension of Micrococcus lysodeikticus (Sigma Chemical Co., St Louis). ${ }^{18}$ A stock suspension of $M$. lysodeikticus of $3 \mathrm{mg} / \mathrm{ml}$ was prepared. Bronchial fluids collected from control and ATP-challenged bronchial tissues were diluted in distilled and deionized water $(1: 4 \mathrm{v} / \mathrm{v})$ and acetic acid was added to adjust the $\mathrm{pH}$ to 4.5 . Samples were then heated at $100^{\circ} \mathrm{C}$ for $2 \mathrm{~min}$ to precipitate impurities. ${ }^{19,20} \mathrm{An}$ aliquot of $200 \mu \mathrm{l}$ of each treated bronchial fluid was added to $1.8 \mathrm{ml}$ of $50 \mathrm{mM}$ potassium phosphate buffer, $\mathrm{pH} 7.4$ containing $M$. lysodeikticus $(300 \mu \mathrm{g} / \mathrm{ml})$, sodium azide $(1 \mathrm{mg} / \mathrm{ml})$, BSA $(1 \mathrm{mg} / \mathrm{ml})$ and incubated at $37^{\circ} \mathrm{C}$ for 2 hours. Standard curves were constructed by incubating egg-white lysozyme (Sigma Chemical Co., St Louis) (0.5 to $100 \mathrm{ng} / \mathrm{ml})$ in $1.5 \mathrm{ml}$ of $50 \mathrm{mM}$ potassium phosphate buffer, $\mathrm{pH} 7.4$ containing
M. lysodeikticus, sodium azide, BSA and incubated at $37^{\circ} \mathrm{C}$ for 2 hours. After incubation, the optical densities were measured at a wavelength of $450 \mathrm{~nm}$ with potassium phosphate, $\mathrm{pH} 7.4$ containing BSA as blank. The lysozyme concentration in each human bronchial fluid was estimated from the standard curve.

\section{Calculation}

The concentration of MUC5AC mucin detected in the fluids derived from human bronchial preparations by the IRMA are expressed as $\mu \mathrm{g}$ of MUC5AC mucin $/ \mathrm{ml}$ and were estimated from the M1 standard curves. Lysozyme concentrations were expressed as $\mathrm{ng} / \mathrm{ml}$. All results are means \pm SEM. Statistical analysis were performed using the Student's $t$-test. A value $(P<0.05)$ was taken as an indication of significance.

\section{Results}

\section{Immunohistochemistry}

MUC5AC mucin in the intracellular organelles of epithelial goblet cells of unstimulated bronchial preparations were labeled with the 1-13 M1 MAb (Fig. 1B) and 21 M1 MAb (Fig. 1C) when compared with the unlabeled control (Fig. 1A). In addition, MUC5AC mucin were observed on the surface epithelium in contact with cilia of ciliated cells (Fig. 1).

Subsequent to a 60-min ATP $(0.1 \mathrm{mM})$ challenge of human bronchial preparations, less labelling of the MUC5AC mucin was observed in the intacellular organelles of goblet cells with the 1-13 M1 MAb (Fig. 2A) and 21 M1 MAb (Fig. 2B). Most goblet cells exhibited weak labelling or were devoid of mucins. However, MUC5AC mucin was detected with the 1-13 M1 and 21 M1 MAbs (Fig. 2A, 2B) in some goblet

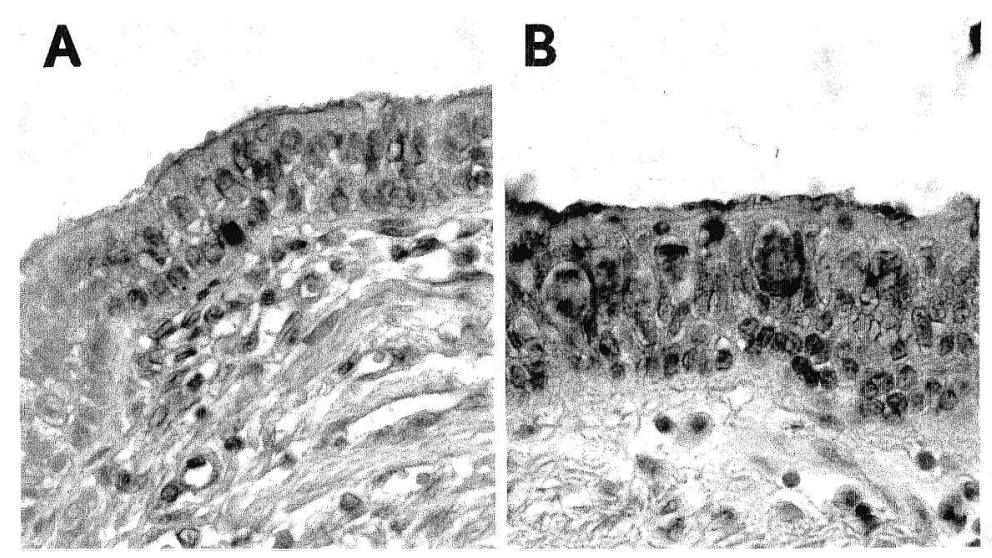

I C

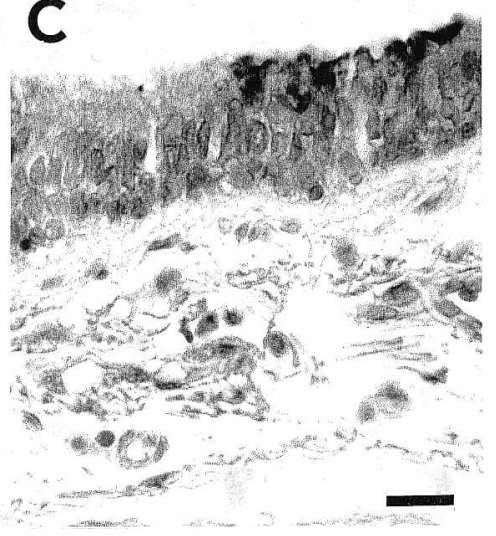

FIG. 1. Immunohistochemical staining of isolated human bronchial preparations with anti-M1 MAbs. No labelling of epithelial goblet cells was observed in the negative control (A). In unstimulated bronchial tissues, goblet cells in the surface epithelium were intensely labelled with the 1-13 M1 MAb (B) and the $21 \mathrm{M} 1 \mathrm{MAb}(\mathrm{C})$. Internal scale bar $=80 \mu \mathrm{m}$. 


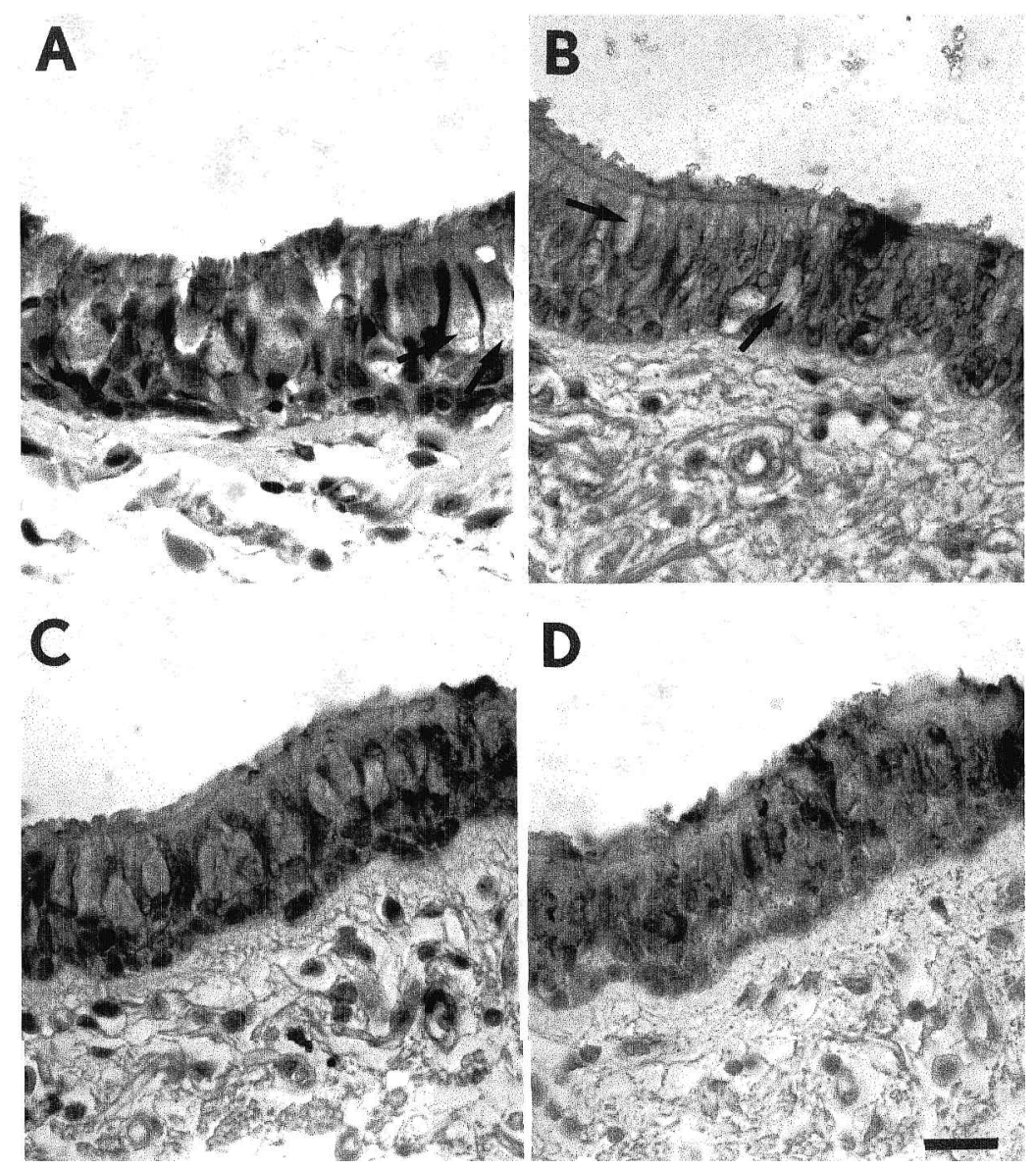

FIG. 2. Immunohistochemical staining of human bronchial preparations with anti-M1 MAbs after stimulation with either ATP $(0.1 \mathrm{mM}$; panels $A$ and $B)$ or UTP $(0.1 \mathrm{mM}$, panels $C$ and D). In ATP-challenged bronchial preparations, intracellular organelles of the epithelial goblet cells were weakly labelled with the 1-13 M1 MAb (A) and 21 M1 MAb (B). Some epithelial goblet cells were devoid of MUC5AC mucin (arrow). In contrast, in bronchial preparations challenged with UTP, MUC5AC mucin in the intracellular organelles of epithelial goblet cells were intensely labelled with the 1-13 M1 MAb (C) and the 21 M1 MAb (D). Internal scale bar $=80 \mu \mathrm{m}$.

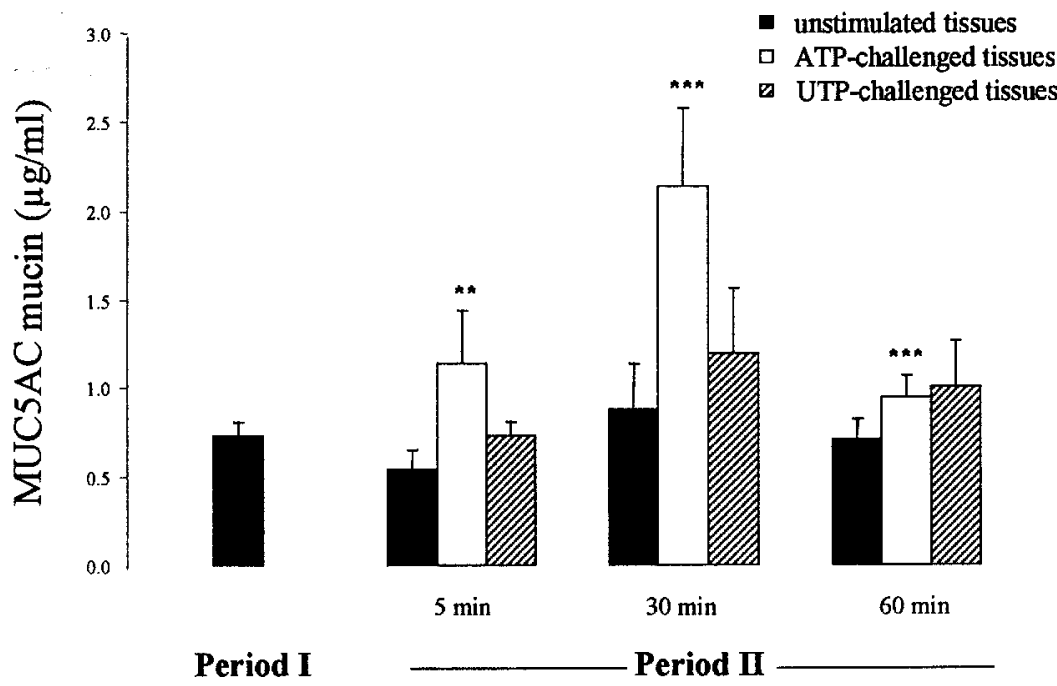

FIG. 3. Detection of MUC5AC mucin released from human bronchial preparations in vitro using an immunoradiometric assay and pooled anti-M1 MAbs (PM8). Data are presented as means \pm SEM and are from Period I (unstimulated tissues; 14 human lungs) and after stimulation with the different agonists (Period II). The effects of ATP $(0.1 \mathrm{mM} ; 14$ human lungs) and UTP $(0.1 \mathrm{mM} ; 6$ human lungs) were analyzed after 5, 30 and $60 \mathrm{~min}$ of stimulation of bronchial preparations.

*** indicates a significant difference $(P<0.001)$ from paired time control bronchial preparations. 


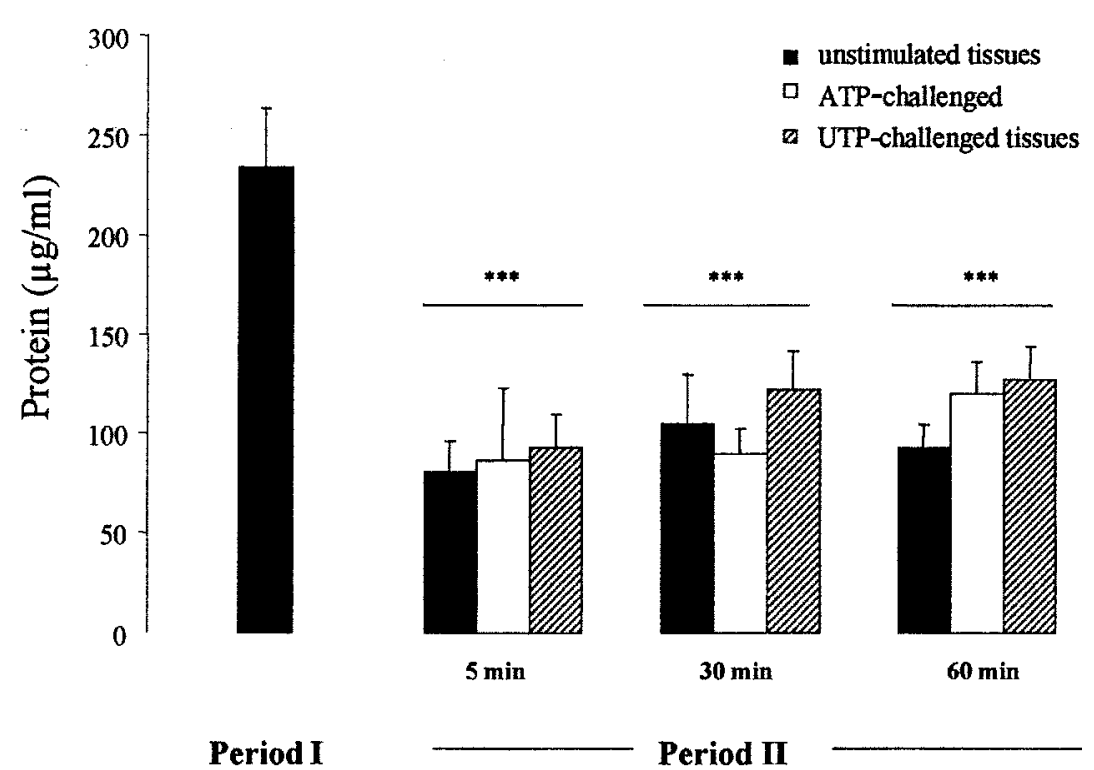

FIG. 4. Protein was determined in fluids derived from unstimulated bronchial preparations and tissues challenged with ATP $(0.1 \mathrm{mM})$ and UTP $(0.1 \mathrm{mM})$. Data are presented as means \pm SEM and are from Period I (unstimulated tissues; 6 human lungs) and after stimulation for 5, 30 and $60 \mathrm{~min}$ (Period II) with ATP $(0.1 \mathrm{mM} ; 6$ human lungs) and UTP $(0.1 \mathrm{mM} ; 6$ human lungs). *** indicates a significant difference $(P<0.001)$ from basal values (Period I).

cells. In bronchial tissues stimulated with UTP $(0.1 \mathrm{mM})$, the intracellular organelles of epithelial goblet cells exhibited the same labelling with the 1-13 M1 and 21 M1 MAbs (Fig. 2C, 2D) as observed in unstimulated bronchial preparations (Fig. 1B, 1C).

\section{MUC5AC mucin release from human bronchial rings: effects of ATP and UTP}

The basal release of MUC5AC mucin from unstimulated human bronchial preparations was: $0.80 \pm$ $0.15 \mu \mathrm{g} / \mathrm{ml}$ (Period I, 21 bronchial preparations from 14 lungs; Fig. 3). This value was not significantly altered during the experimental protocol under control conditions (Period II). When bronchial preparations were stimulated with either ATP $(0.1 \mathrm{mM})$ or UTP $(0.1 \mathrm{mM})$ at 10 second intervals from 10 to 60 seconds, no detectable release of MUC5AC mucin from bronchial tissues was observed (21 bronchial preparations from one lung; data not shown). However, a significant increase in the MUC5AC mucin concentrations measured in bronchial fluids derived from human preparations was observed after 5, 30 and 60 minutes challenge with ATP $(0.1 \mathrm{mM})$ when compared with paired control preparations from the same human lungs (Fig. 3). In contrast, no significant increase in the MUC5AC mucin release from goblet cells was detected when bronchial preparations were stimulated with UTP $(0.1 \mathrm{mM})$.

\section{Protein release from human bronchial preparations}

A significant decrease in the concentration of total proteins measured in bronchial fluids derived from human preparations was observed during the experimental protocol (Period I versus Period II; Fig. 4). However subsequent to a $5 \mathrm{~min}, 30 \mathrm{~min}$ or $60 \mathrm{~min}$ challenge of human bronchial preparations with either ATP $(0.1 \mathrm{mM})$ or UTP $(0.1 \mathrm{mM})$, no significant difference in the protein concentrations was observed when results from ATP or UTP-challenged bronchial preparations were compared with control preparations at each time interval (Period II; Fig. 4).

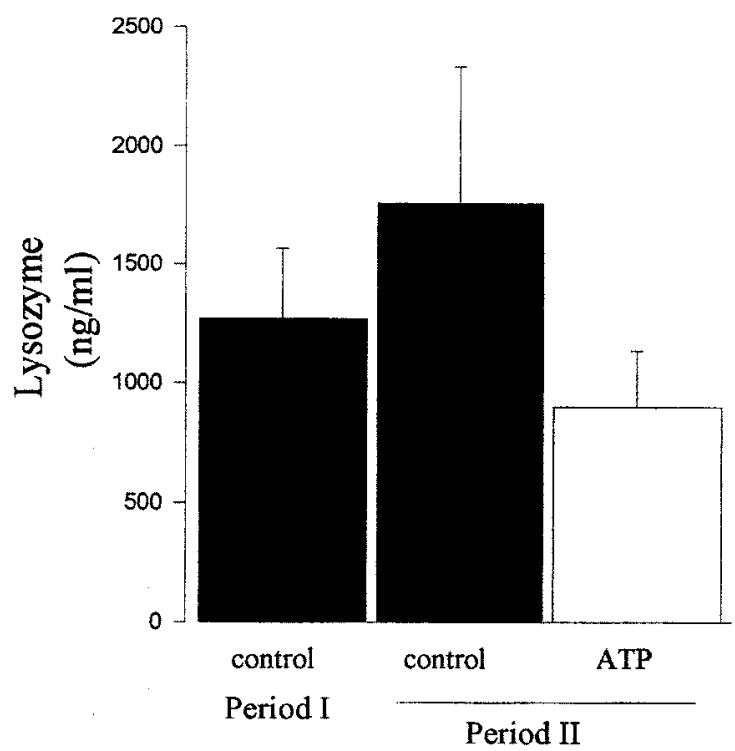

FIG. 5. Lysozyme was determined in the bronchial fluids derived from human preparations obtained at Period I (3 human lungs) and after a 60 min-challenge with ATP (0.1 mM; Period II; 8 human lungs). Values obtained from ATP challenged-tissues (open bar) were compared with paired controls (solid bar). Values are means \pm SEM for control and ATP-treated bronchial tissues. 
Effect of ATP on lysozyme and mucin release from bronchial submucosal glands

Stimulation of human bronchial preparations with ATP $(0.1 \mathrm{mM})$ for 60 minutes had no significant effect either on lysozyme release from bronchial tissues (Fig. 5 ) or on the release of mucins from glandular cells as demonstrated by the intense PAS-staining of the submucosal glands in ATP-challenged bronchial tissues $(0.1 \mathrm{mM}$; Fig. 6B). However, while epithelial goblet cells and glands exhibited a strong PAS-staining in unstimulated tissues (Fig. 6A), few PAS-positive epithelial goblet cells were observed after ATP challenge of bronchial preparations (Fig. 6B).

\section{Discussion}

This study provides evidence that MUC5AC mucin was detected in goblet cells of the surface epithelium of human airways. ATP reduced the immunohistochemical labelling of epithelial goblet cells and was associated with a significant increased accumulation of MUC5AC mucin in the bronchial fluids derived from human tissues. The quantities of protein and lysozyme detected in the fluids derived from ATP-challenged bronchial preparations were not significantly altered compared with unstimulated preparations. In addition, while the PAS staining of the submucosal glands was not altered in bronchial

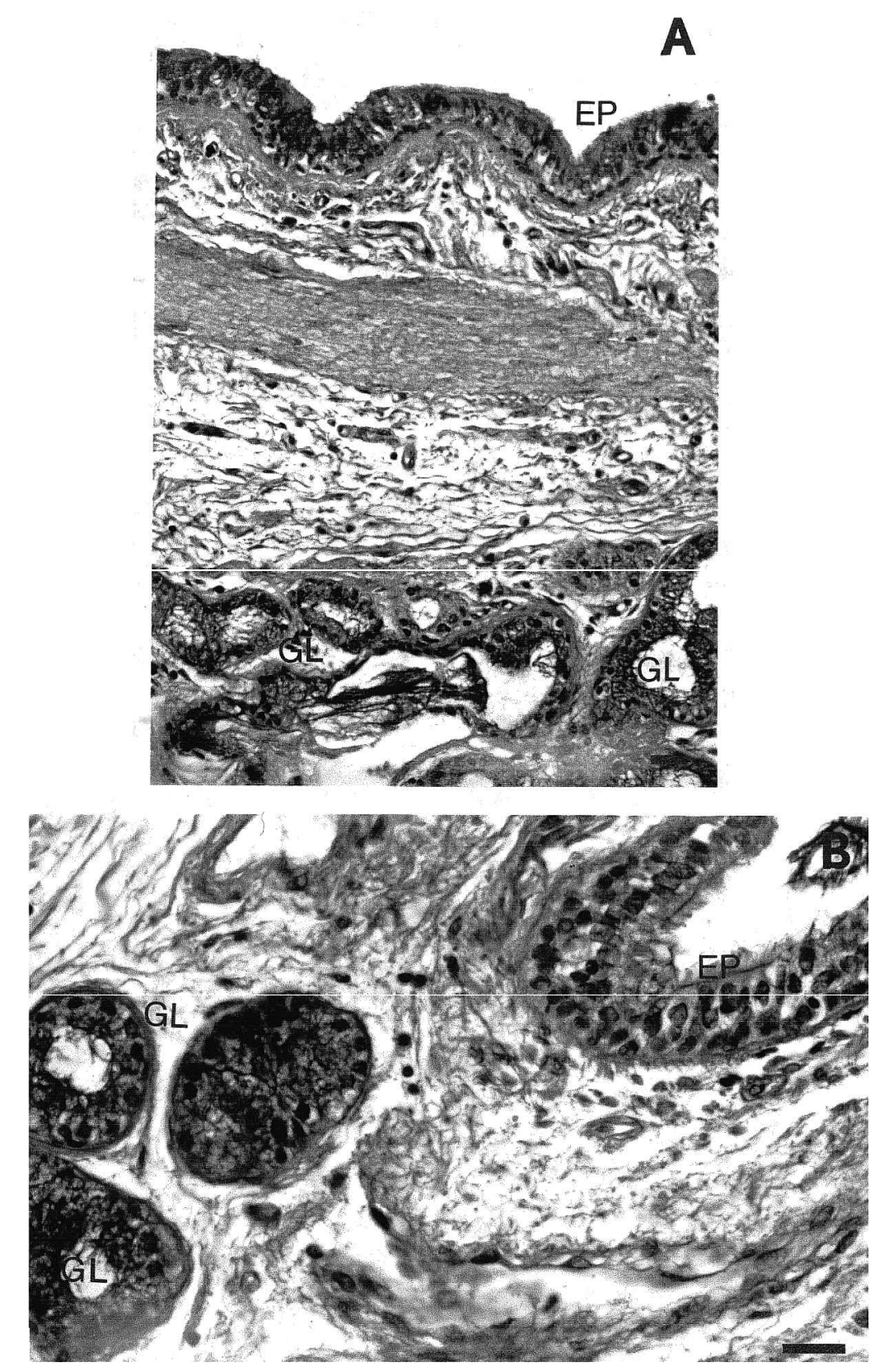

FIG. 6. PAS-staining of unstimulated human bronchial preparations (panel A) and tissues challenged with ATP for 60 min (panel $B$ ). An intense staining of mucins was observed in the lumen of the submucosal glands (GL) of the unstimulated and ATPchallenged bronchial preparations (A, B). While epithelial goblet cells of unstimulated tissues were PAS-positive (A), goblet cells of the surface epithelium (EP) of ATP-challenged tissues were not stained (B). Internal scale bar $=160 \mu \mathrm{m}$. 
tissues stimulated with ATP, a reduced staining of mucins was observed in the goblet cells of the airway surface epithelium. Challenge of human bronchial preparations with UTP did not modify the release of either MUC5AC mucin or protein from human bronchial preparations. These results suggest that ATP challenge of human bronchial preparations may be associated with the release of MUC5AC mucin from human bronchial epithelial goblet cells.

Several mucin genes have been identified in the human respiratory tract. MUC1, MUC2, MUC3 and MUC5AC mRNAs were detected in the surface epithelium and MUC4, MUC5B, MUC5AC, MUC8 mRNAs were present in the submucosal glands. ${ }^{21-24}$ Of these, MUC5AC and MUC5B were the only mucin gene products isolated from normal human airway secretions. $^{25,26}$ The MAbs used (present report) labelled goblet cells of the bronchial epithelium ${ }^{11}$, cells which are known to express predominantly the MUC5AC mucin gene. ${ }^{22}$

Although MUC5AC mucin was detected in the intracellular organelles of epithelial goblet cells of unstimulated and UTP-challenged bronchial tissues, less labelling was observed in preparations challenged for $60 \mathrm{~min}$ with extracellular ATP $(0.1 \mathrm{mM}$; present report). Previous data ${ }^{4-6}$ clearly showed that isolated airway epithelial goblet cells were activated by extracellular ATP $(0.1 \mathrm{mM})$ and that the goblet cell degranulation was extremely rapid since this phenomenon reached a plateau within 5 minutes after challenge of isolated goblet cells and within 10 minutes after challenge of airway explants with ATP. ${ }^{4}$ While there is evidence that ATP is rapidly metabolized $^{27}$ to ADP and adenosine, these metabolites do not appear to alter either cAMP levels ${ }^{28}$ or mucin secretion $^{5,9}$, suggesting that ATP is the principal neurotransmitter involved in the secretory activity. In addition, the rapid degranulation of epithelial goblet cells observed in lung explants ${ }^{4}$, pancreatic epithelial cells ${ }^{29}$ and the significant increase in the release of MUC5AC mucin after a 5 minute challenge of bronchial preparations with ATP (present report) support the notion that ATP provoked a rapid release of MUC5AC mucin from human airway epithelial goblet cells. These data (present study) support the observations of Shin et al., ${ }^{30}$ who demonstrated that ATP caused mucin release from rat airways in vivo. Furthermore, a low basal degranulation rate in human bronchial explants which was similar to that reported in canine goblet cells has been reported. ${ }^{4}$ The data (present report) confirm this observation since there was a low and constant level of MUC5AC mucin detected in the medium surrounding the unstimulated human bronchial preparations, suggesting a continuous release of MUC5AC mucin. The results (present report) also demonstrated a preferential activity of ATP at the epithelial layer since few secretory granules of epithelial goblet cells were positive after ATP challenge when compared with unstimulated preparations. In contrast, there was always a comparable PAS staining of the bronchial submucosal glands in untreated and stimulated tissues.

The detection of lysozyme has frequently been used as an index of the secretory activity of submucosal glands in tissues derived from the respiratory tract of several species ${ }^{18}$ including man. ${ }^{23,31}$ In the present study, extracellular ATP did not modify the release of lysozyme from the submucosal gland cells since the levels detected in the fluids obtained from bronchial tissues challenged with this agent were not significantly different from controls.

The inflammatory response in the human respiratory tract has often been associated with increased mucus production. The data derived from human airways (present report) suggest that a perturbation at the neuronal level may also be involved in the increased levels of sputum which are frequently observed in patients with airway diseases. While further work is needed to identify the receptors involved, the present data extend the initial observations that extracellular ATP, in addition to evoking degranulation of goblet cells ${ }^{4}$ also induced the release of MUC5AC mucin from human bronchial preparations. These results suggest that purinergic agonists may play a role in the release of gene products from human goblet cells.

ACKNOWLEDGEMENTS. The authors would like to thank Dr. E. Dulmet and her associates in the laboratory of anatomopathology of the Centre Chirurgical Marie Lannelongue for their excellent technical assistance.

\section{References}

1. Kim KC, Wasano K, Niles RM, Schuster JE, Stone PJ, Brody JS. Human neutrophil elastase releases cell surface mucins from primary cultures of hamster tracheal epithelial cells. Proc Natl Acad Sci USA 1987: 84: 9304-9308.

2. Adler KB, Fischer BM, Li H, Choe NH, Wright DT. Hypersecretion of mucin in response to inflammatory mediators by guinea pig tracheal cells in vitro is blocked by inhibition of nitric oxide synthase. $A m J$ Respir Cell Mol Biol 1995: 13: 526-530.

3. Adler KB, Akley NJ, Glasgow W. Platelet-activating factor stimulates release of mucin-like glycoproteins by guinea pig tracheal epithelium in air/liquid interface culture via a lipoxygenase-dependent mechanism. Am J Respir Cell Mol Biol 1992: 6: 550-556.

4. Lethem MI, Dowell ML, Van Scott M, Yankaskas JR, Egan T, Boucher RC, Davis CW. Nucleotide regulation of goblet cells in human airway epithelial explants: normal exocytosis in cystic fibrosis. Am J Respir Cell Mol Biol 1993: 9: 315-322.

5. Davies CW, Dowell ML, Lethem M, Van Scott M. Goblet cell degranulation in isolated canine tracheal epithelium: response to exogenous ATP, ADP, and adenosine. Am J Physiol (Cell Physiol) 1992: 262: C1313-C1323.

6. Kim KC, Zheng QX, Van-Seuningen I. Involvement of a signal transduction mechanism in ATP-induced mucin release from cultured airway goblet cells. Am J Respir Cell Mol Biol 1993: 8: 121-125.

7. Logun C, Mullol J, Rieves D, Hoffman A, Johnson C, Miller R, Goff J, Kalliner M, Shelhamer J. Use of monoclonal antibody enzyme-linked immunosorbent assay to measure human respiratory glycoprotein production in vitro. Am J Respir Cell Mol Biol 1991: 5: 71-79.

8. Kim KC, Nassiri J, Brody JS. Mechanisms of airway goblet cells mucin release: studies with cultured tracheal surface epithelial cells. $A m$ Respir Cell Mol Biol 1989: 1: 137-143.

9. Shimura S, Sasaki T, Nagaki M, Takishima T, Shirato K. Extracellular ATP regulation of feline tracheal submucosal gland secretion. Am J Physiol (Lung Cell Mol Physiol) 1994: 267: L159-L164. 
10. Niles RM, ChristensenTG, Breuer R, Stone PJ, Snider GL. Serine proteases stimulate mucous glycoprotein release from hamster tracheal ring organ culture. J Lab Med 1986: 108: 489-497.

11. Labat C, Bara J, Gascard JP, Sossé-Alaoui H, de Montpreville VT, Yeadon M, Brink C. M1/MUC5AC mucin released by human airways in vitro. Eur Respir J 1999: 14: 390-395.

12. Sossé Alaoui H, Labat C, Gorenne I, de Montpreville VT, Bara J, Brink C Glycoconjugate secretion in human airways in vitro: effects of epithelium removal. Mediators of Inflammation 1998: 7: 25-30.

13. Bara J, Gautier R, Daher N, Zaghouani H, Decaens C. Monoclonal antibodies against oncofetal mucin M1 antigens associated with precancerous colonic mucosae. Cancer Res 1986: 46: 3983-3989.

14. Bara J, Chastre E, Mahiou J, Singh RL, Forgue-Lafitte ME, Hollande E, Godeau F. Gastric M1 mucin, an early oncofetal marker of colon carconigenesis, is encoded by the MUC5AC gene. Int J Cancer 1998: 75: $767-773$.

15. Van den Ingh HF, Bara J, Cornelisse CJ, Nap M. Aneuploidy and expression of gastric-associated mucus antigens M1 and CEA in colorectal adenomas. Am J Clin Pathol 1987: 87: 174-179.

16. Bara J, Gautier R, Le Pendu J, Oriol R. Immunochemical characterization of mucins. Polypeptide (M1) and polysaccharide (A and Le ${ }^{\mathrm{b}}$ ) antigens. Biochem J 1988: 254: 185-193.

17. Lowry OH, Rosebrough NJ, Farr AL, Randall RJ. Protein measurement with the Folin Phenol reagent. J Biol Chem 1951: 193: 265-275.

18. Webber SE. The effects of peptide histidine isoleucine and neuropeptide $\mathrm{Y}$ on mucus volume output from the ferret trachea. Br J Pharmaco 1988: 95: 49-54.

19. Petit JF, Jolles P. Purification and analysis of human saliva lysozyme. Nature 1963: 200: 168-169.

20. Roger P, Gascard J-P, de Montpreville VT, Brink C. Basal secretion of lysozyme from human airways in vitro. Mediators of Inflammation 1999: 8: 319-323

21. Audie JP, Janin A, Porchet N, Copin MC, Gosselin B, Aubert JP. Expression of human mucin genes in respiratory, digestive, and reproductive tracts ascertained by in situ hybridization. J Histochem Cytochem 1993: 41 : 1479-1485.
22. Reid CJ, Could S, Harris A. Developmental expression of mucin genes in the human respiratory tract. Am J Respir Cell Mol Biol 1997: 17: 592-598.

23. Dohrman A, Tsuda T, Escudier E, Cardone M, Jany B, Gum J, Kim Y, Basbaum C. Distribution of lysozyme and mucin (MUC2 and MUC3) mRNA in human bronchus. Exp Lung Res 1994: 20: 367-380.

24. ShankarV, Pichan P, Eddy RL, TonkV, Sait SN, ShowsTB, Schultz RE, Gotway G, Elkins RC, Gilmore MS, Sachdev GP. Chromosomal localization of a human mucin gene (MUC8) and cloning of the cDNA corresponding to the carboxy terminus. Am J Respir Cell Mol Biol 1997: 16: 232-241.

25. Hovenberg HW, Davies JR, Herrmann A, Linden CJ, Carlstedt I. MUC5AC, but not MUC2, is a prominent mucin in respiratory secretions. Glycoco nj J 1996: 13: 839-847.

26. Thornton DJ, Howard M, Khan N, Sheehan JK. Identification of two glycoforms of the MUC5B mucin in human respiratory mucus. $J$ Biol Chem 1997: 272: 9561-9566.

27. Schulman ES, Glaum MC, Post T, Wang Y, Raible DG, Mohanty J, Butterfield JH, Pelleg A. ATP modulates anti-IgE-induced release of histamine from human lung mast cells. Am J Respir Cell Mol Biol 1999: 20: $530-537$.

28. Chan HC, Zhou WL, Fu WO, Ko WH, Wong PY. Different regulatory pathways involved in ATP-stimulated chloride secretion in rat epididymal epithelium. J Cell Physiol 1995: 164: 271-276.

29. Montserrat C, Merten M, Figarella C. Defective ATP-dependent mucin secretion by cystic fibrosis pancreatic epithelial cells. FEBS Lett 1996: 393: $264-268$

30. Shin CY, Kim KC, Lee WJ, Jo MJ, Park KH, Dalby R, Ko KH. Inhaled ATP causes mucin release from goblet cells of intact rats. Exp Lung Res 1999: 26: 1-11.

31. Konstan MW, Chen PW, Sherman JM, Thomassen MJ, Wood RE, Boat TF. Human lung lysozyme: sources and properties. Am Rev Respir Dis 1981: 123: $120-124$

\section{Received 24 October 2000;}

accepted after revision 14 November 2000 


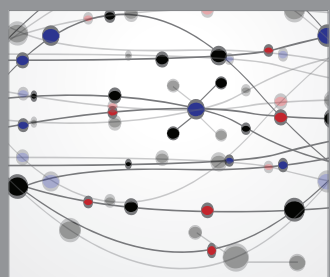

The Scientific World Journal
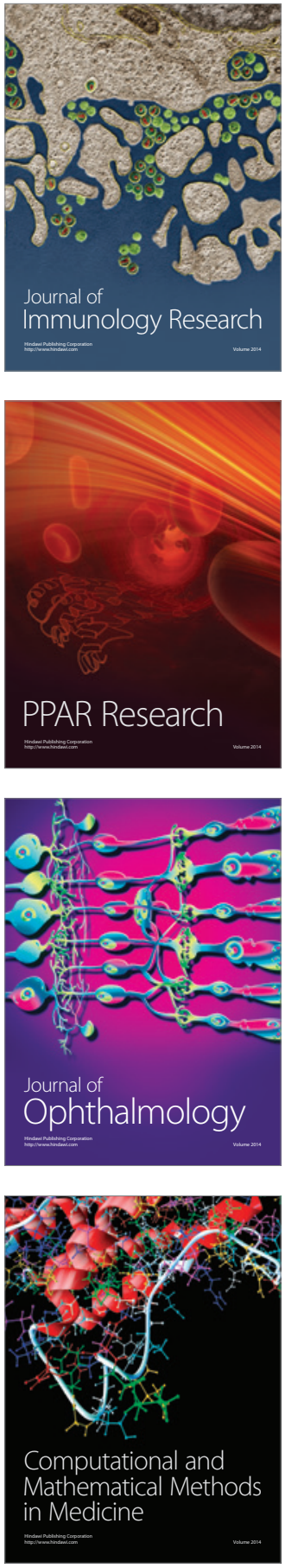

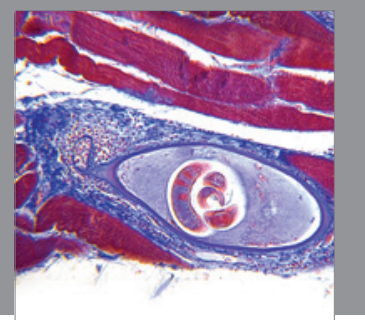

Gastroenterology

Research and Practice
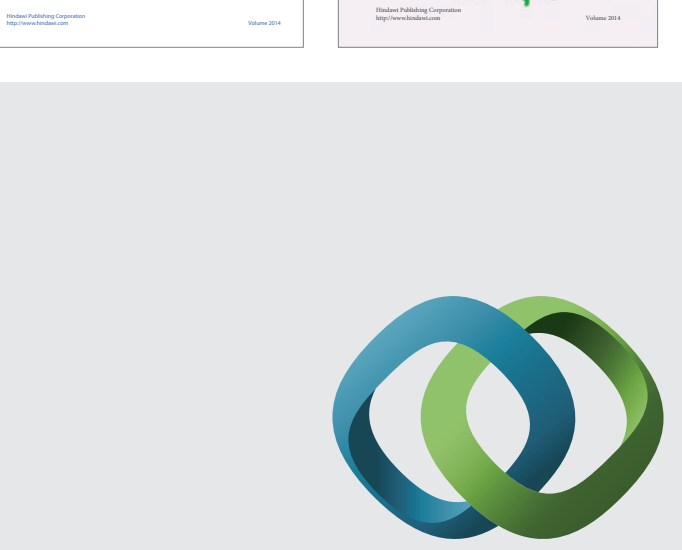

\section{Hindawi}

Submit your manuscripts at

http://www.hindawi.com
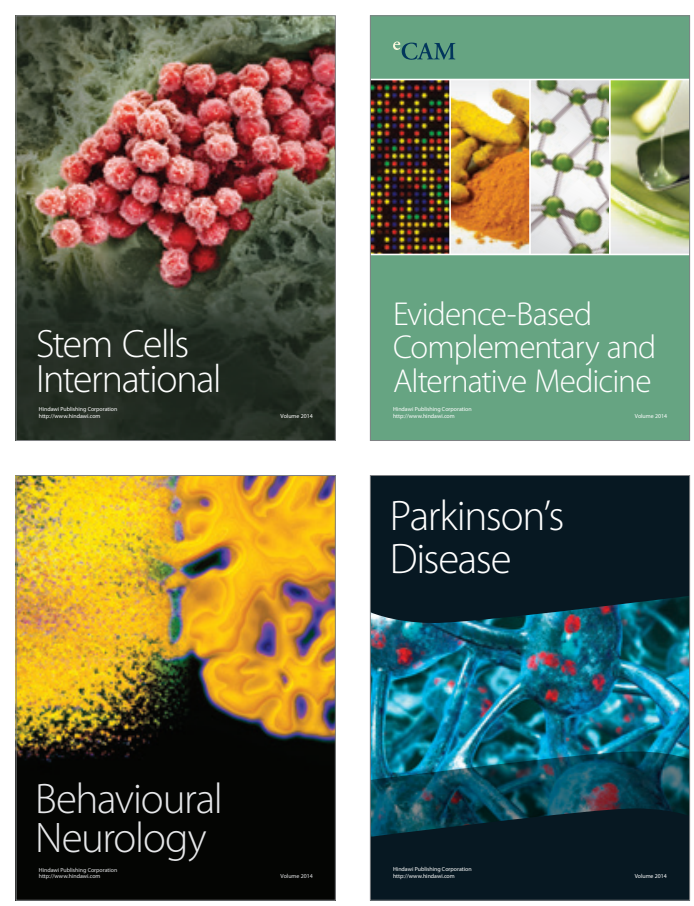

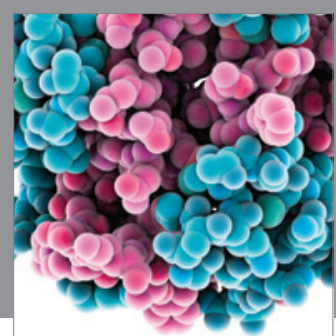

Journal of
Diabetes Research

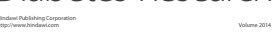

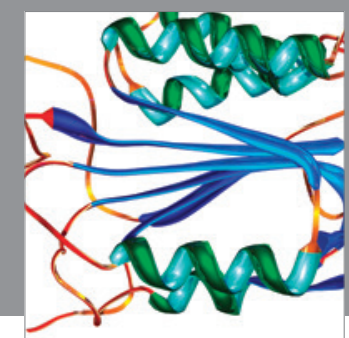

Disease Markers
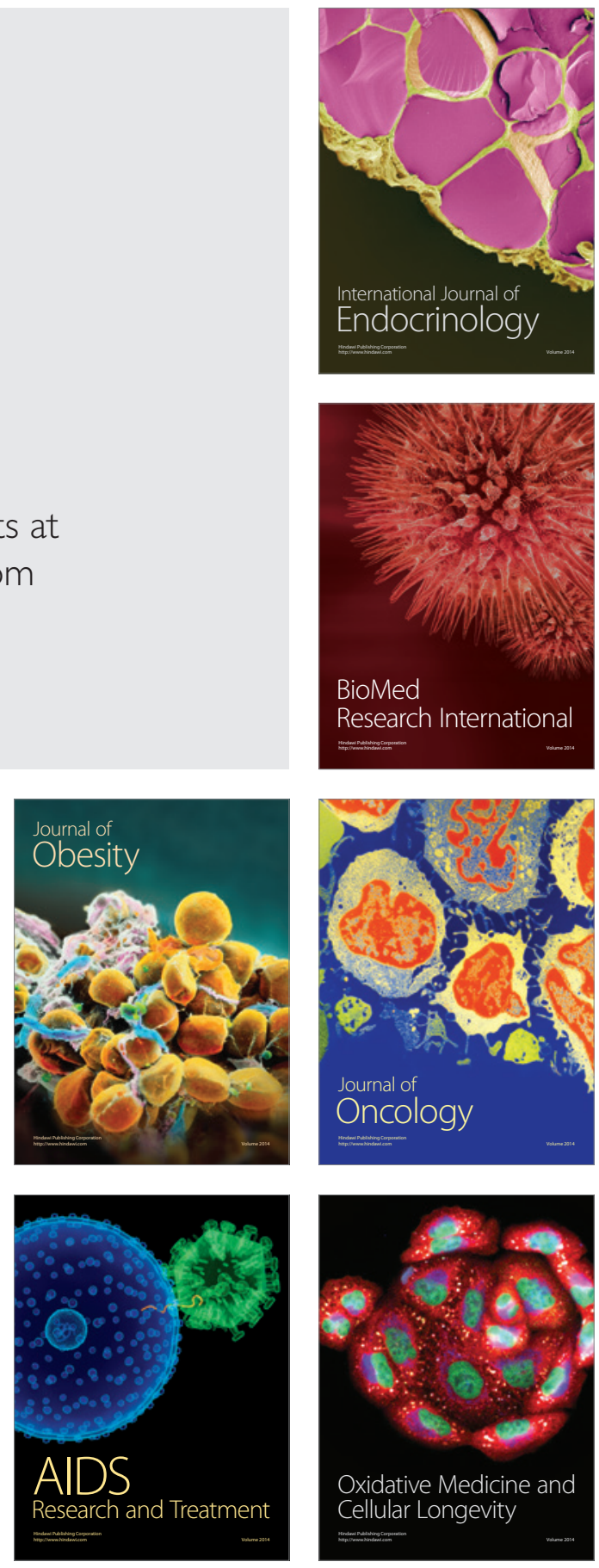